\title{
International Journal of Applied Microbiology and Biotechnology
} Research

www.bluepenjournals.org/ijambr

\section{Effects of Irvingia species leaf extract on Streptococcus pneumoniae infected albino rats}

\author{
Arikekpar Ibemologi ${ }^{1 *}$, Alade Tolulupe ${ }^{1}$ and Langley A. Orutugu ${ }^{2}$ \\ ${ }^{1}$ Department of Medical Laboratory Science, Faculty of Basic Medical Sciences, College of Health Sciences, \\ Niger Delta University, Wilberforce Island, Amassoma, P. M. B. 071, Bayelsa State, Nigeria. \\ ${ }^{2}$ Department of Medical Microbiology and Parasitology, Faculty of Basic Medical Sciences, \\ College of Health Sciences, Niger Delta University, Amassoma, Wilberforce Island, Nigeria.
}

\begin{abstract}
Article History
Received 23 October, 2018

Received in revised form 10 December, 2018

Accepted 13 December, 2018

Keywords:

Antimicrobial activity, Post-infection

Irvingia sp.,

Oral administration, Health benefits.
\end{abstract}

Article Type:

Full Length Research Article

\begin{abstract}
Streptococcus pneumoniae causes pneumonia and bacterial meningitis, and bacteremia in children. Irvingia sp. or African Bush Mango has nutritional and health benefits and their leaf extracts and other parts have been documented to possess antimicrobial activity, which can be exploited to ameliorate the scourge of antibiotics resistance. In this study, 30 out of 35 albino rats were intraperitoneally challenged with $S$. pneumoniae, followed by oral administration of leaf extract of Irvingia sp. The rats exhibited sluggishness, ruffled fur, inappetence and hunch back posture, but recovered from the fourth day after oral administration of Irvingia sp. leaf extract. The mean body weights of the rats were $175 \pm 1.9 \mathrm{~g}$ and $176 \pm 1.5 \mathrm{~g}$ in the test and the control groups, respectively on the first day of the experiment. The mean body weight of the test group $(173 \pm 7 \mathrm{~g})$ was lower than the control group $(182 \pm 40.5 \mathrm{~g})$ on the sixth day of post-infection $(P=0.65)$. The mean value of food intake by the rats for base line $(27.95 \pm 5.3 \mathrm{~g})$ was higher than the third day $(17.35 \pm 2.2 \mathrm{~g})$ corresponding with inappetence observed in the rats in the test group.
\end{abstract}

(C2019 BluePen Journals Ltd. All rights reserved

\section{INTRODUCTION}

Streptococcus pneumoniae is a Gram positive cocci, $\alpha$ hemolytic bacteria (Arora and Arora, 2012) and a facultative anaerobe with virulent strains producing capsular polysaccharide colonies on blood agar, but anaerobic incubation gives off $\beta$-haemolysis (Mandell et al., 2007; Cardozo et al., 2006; Arora and Arora, 2012). $S$. pneumoniae is leading causative agent of community acquired pneumonia and can frequently cause localized infections, acute otitis media, pneumonia, meningitis, and bacteremia in humans (Mandell et al., 2007; Hausdorff et al., 2005).

S. pneumoniae can be injected into adult rats intrapulmonarily, infant rats are injected intrabronchially and other methods of inoculation may include intrathoraic

\footnotetext{
*Corresponding author. E-mail: ariko20002000@yahoo.com.
}

and intraperitoneal methods (Candiani et al., 1997; Smith and Abbott, 1994; Alexander et al., 1994). The routes of drug administration to the rats include intravenously (I.V) into their tail veins, subcutaneously (S.C), intramuscularly (I.M), intraperitoneally or orally (Aarde et al., 2013; Hollister-Lock et al., 2013).

Irvingia gabonensis which is also known Bush Mango or African Mango due to its similarity to mango is an economically important tree native to most tropical forests in West and Central Africa (Lowe et al., 2000; Harris et al., 1996). Some uses of Irvingia spp. may include, edible purposes, antidiabetics, regulating serum cholesterol levels, weight management, analgesic properties, dysentery treatment, dental care and also as antibacterials and antifungals (Okolo et al., 1995; Ngondi et al., 2005; Ayuk et al., 1999).

The leaf extracts of $l$. gabonensis contain phytochemicals that confers antibiotic activities against 
Table 1. Protocols for Streptococcus pneumoniae (SP) injection and treatment with Irvingia sp. Paste.

\begin{tabular}{ll}
\hline Treatment groups & Treatment \\
\hline Group 1(control) & Rats were only given feed and water with no SP inoculation and no Irvingia administration \\
Group 2 & Each rat was injected with $1 \mathrm{ml}$ of SP with no Irvingia extract paste administration \\
Group 3 & Each rat was injected with $1 \mathrm{ml}$ of SP with $50 \mathrm{mg} / \mathrm{kg} / \mathrm{bw}$ of Irvingia extract paste after $24 \mathrm{~h}$ \\
Group 4 & Each rat was injected with $1 \mathrm{ml}$ of SP with $100 \mathrm{mg} / \mathrm{kg} / \mathrm{bw}$ of Irvingia extract paste after $24 \mathrm{~h}$ \\
Group 5 & Each rat was injected with $1 \mathrm{ml}$ of SP with $250 \mathrm{mg} / \mathrm{kg} / \mathrm{bw}$ of Irvingia extract paste after 24 \\
Group 6 & Each rat was injected with $1 \mathrm{ml}$ of SP with $500 \mathrm{mg}$ of Irvingia extract paste after $24 \mathrm{~h}$ \\
Group 7 & Each rat was injected with $1 \mathrm{ml}$ of SP with Lethal doses of $5500,6000,6500,7000$ and 7500 \\
\hline
\end{tabular}

SP, Streptococcus pneumoniae injection; $\mathbf{m g} / \mathbf{k g b w}$, milligram per kilogram body weight (Ayodele et al., 2015).

Escherichia coli and Staphylococcus aureus (George and Zhao, 2007). These constituents include saponin, flavonoids, tannins, cardiac glycoside, anthraquinones and alkaloids (Oluwafemi et al., 2014).

Pneumococci resistance to antibiotics has been well documented by several authors (Appelbaum et al., 1997; Emele, 2000; Doern et al., 2001; Benbachir et al., 2001). Due to the some undesirable side effects caused by orthodox therapies, attention is gradually shifting to plants which have been demostrated as a good source of drugs (Shakya et al., 2010; Samadder and Khuda-Bukhsh, 1994).

\section{MATERIALS AND METHODS}

\section{Sample size and sampling technique}

A total of 35 adult rats were used for the study by simple random sampling technique. Sample size was determined by Resource equation method (Fitts, 2011).

\section{Plant collection and processing}

Fresh leaves I. gabonensis were collected from a farm land in Kaiama, Bayelsa State of Nigeria. The leaves of $I$. gabonensis were air-dried under the sun for three (3) weeks and grinded manually with a blender into fine powder, sieved and well packed in a sterile polythene bag. It was stored in a dry place avoiding cold air, water or moisture contact. On extraction, $225 \mathrm{~g}$ of the fine grinded leaf were measured out and poured into $350 \mathrm{ml}$ of $80 \%$ ethanol. The solution was properly mixed within 3 $\mathrm{h}$ and allowed to stand for $48 \mathrm{~h}$ at room temperature $\left(25 \pm 2^{\circ} \mathrm{C}\right)$. After the $48 \mathrm{~h}$ of standing, the dissolved solution of powdered leaf and ethanol was filtered by means of filter paper carefully into a clean glass cylinder. The filtrate was then placed in water bath and dried to evaporation by heat $\left(45^{\circ} \mathrm{C}\right)$ until the filtrate forms a paste, and stored in sterile containers at $4^{\circ} \mathrm{C}$, in the refrigerator for later use (Malann et al., 2014).

\section{Experimental animal collection and design}

Thirty-five adult albino rats were housed in netted and aerated decent cages in the animal house of the Department of Medical Laboratory Science. On arrival, the mean \pm standard deviation body weights of rats were $127 \pm 2.5 \mathrm{~g}$. The rats were fed constantly with growers mash for 28 days and then weighed on Day 1, Day 3 and Day 6 of this experiment. The rats were divided into seven groups of five per group as shown in the Table 1 .

\section{Collection and storage bacteria strain}

Strain samples were collected from sputum samples at Federal Medical Centre, Yenagoa, Bayelsa State, Nigeria and were confirmed by Optochin sensitivity (Richard et al., 1997) and bile solubility testing, after isolation in $5 \%$ sheep blood agar supplemented with $10 \mathrm{mg}$ of gentamycin powder-an antibiotic selective for $S$. pneumoniae growth (Murray et al., 2003).

\section{Harvesting and preparation of inoculum}

Colonies of the $S$. pneumoniae were harvested with a sterile wire loop and introduced into $5 \mathrm{ml}$ of Tryptic soy broth and incubated overnight. Organisms were sedimented by centrifugation and mixed with sterile phosphate-buffered saline until they matched the turbidity standard-McFarland Equivalence Turbidity Standards (0.5). A 10 fold serial dilution was done and plated on blood agar plates to ascertain the number of viable bacteria as colony forming unit per $\mathrm{ml}$ (Benjamin et al., 2006). 
Table 2. Observations from day three to day five.

\begin{tabular}{|c|c|c|c|c|}
\hline \multirow{2}{*}{ Group } & \multirow{2}{*}{ Treatment } & \multicolumn{3}{|c|}{ Observation } \\
\hline & & Day 3 & Day 4 & Day 5 \\
\hline 1 & No Irvingia spp. paste & Normal & Normal & Normal \\
\hline 2 & $1 \mathrm{ml}$ of SP and no Irvingia spp. paste & Abnormal & Abnormal & Abnormal \\
\hline 3 & $1 \mathrm{ml}$ of SP $+50 \mathrm{mg} / \mathrm{kg}$ of Irvingia spp. paste & Abnormal & Abnormal & Abnormal \\
\hline 4 & $1 \mathrm{ml}$ of SP $+100 \mathrm{mg} / \mathrm{kg}$ of Irvingia spp. paste Irvingia spp. paste & Abnorma & Abnormal & Abnormal \\
\hline 5 & $1 \mathrm{ml}$ of SP $+250 \mathrm{mg} / \mathrm{kg}$ of Irvingia spp. paste & Abnormal & Abnormal & Abnormal \\
\hline 6 & $1 \mathrm{ml}$ of SP $+500 \mathrm{mg} / \mathrm{kg}$ of Irvingia spp. paste & Abnormal & Abnormal & Abnormal \\
\hline 7 & $\begin{array}{l}1 \mathrm{ml} \text { of SP + lethal doses of } 5,500,6000,6500,7000 \text { and } 7500 \\
\mathrm{mg} / \mathrm{kg} \text { of Irvingia spp. paste }\end{array}$ & LDA & LA & LA \\
\hline
\end{tabular}

Normal, Active, raised fur, normal appetite; Abnormal, sluggishness, Inappetance and hunched back posture; LDA, lethal dose administered; LA, low activity and Inappetance; SP, Streptococcus pneumoniae injection.

\section{Inoculation of bacterial inoculm}

About $1 \mathrm{ml}$ each of the $S$. pneumoniae inoculum was administered into the intraperitoneal cavity of the rats using a 29 wire gauge needle insulin syringe after sterilizing with $70 \%$ alcohol and the animals were observed immediately after the injection for any signs of distress or illness (Benjamin et al., 2006).

\section{Irvingia extracts treatment of infected rats}

On Day 2, twenty-five rats in the Groups 3-7 were treated with varying doses of leaf extract of Irvingia injected intraperitoneally after $S$. pneumoniae injection on Day 1 (Richard et al., 2004; Mukherjee, 2002).

\section{Rat daily body weight and mass of food ingested}

The rats body weights were measured every morning and fed from metal cups specifically designed to minimize food spillage; and the daily food intake of each rat was determined directly by weighing the cup just before and after refilling (Darsaud et al., 2003).

\section{Termination of treatments and collection of blood sample}

Bacteremia was accessed on Days 4 and 6 , as the dorsal veins of rats from all groups were sterilized with $80 \%$ ethanol and punctured with sterile lancet, then $0.01 \mathrm{ml}$ was spread on $5 \%$ sheep blood agar and incubated at $37^{\circ} \mathrm{C}$ (Richard et al., 1997, 2004).

\section{Statistical analysis}

Data in Table 4 were analyzed with Two Sample T-test and the P-values for the body weights of the test and control rat groups for Days 1,3 and 6 were $0.23,<0.001$ and 0.65 , respectively, while that for the food intake in test and control rat groups were $0.72,<0.001$ and 0.034 .

\section{RESULTS}

Twenty four hours after intraperitoneal inoculation of the rats in Groups 2-7 with S. pneumoniae, they exhibited Inappetence, ruffled fur, sluggishness and hunched back posture. However, these symptoms were not observed in rats from Group 1 that were not inoculated with $S$. pneumoniae.

Rats in Group 2 showed sluggishness and drastic loss of appetite by Day 3 after they were infected with $S$. pneumoniae on Day 1 but Irvingia sp. paste was not orally administered by Day 2. Rats from Groups 3, 4, 5 and 6 were given oral administration of Irvingia sp. paste by Day 2 after they were infected with $S$. pneumoniae on Day 1, and they showed reduced sluggishness and lack of appetite compared to those in Group 2 (Table 2).

Results of Days 4 and 5 shows that rats, across Groups 1 to 6 exhibited similar results as shown in Day 3. However, when lethal doses of 5, 500,6000, 6500, 7000 and $7500 \mathrm{mg} / \mathrm{body}$ weight of Irvingia sp. paste were administered to different rats in Group 7, rats showed low activity and inappetence.

Observations on Days 6, 7 and 8 from Table 3, showed that Groups 3 to 6 became active with improved appetite. Group 2 also showed improved appetite but low activity compared to the rats in Groups 3-6. On Day 6, rats in Group 7 that had oral administration of 6500 and 7000 $\mathrm{mg} / \mathrm{kg}$ bodyweight of Irvingia sp. paste died.

On Day 1 the mean body weight for test Groups 2-7 was $175 \pm 1.9 \mathrm{~g}$ and in the control group, it was $176 \pm 1.5 \mathrm{~g}$. That for Day 3 was $169 \pm 13.3 \mathrm{~g}$ for the test groups and $179 \pm 2.6 \mathrm{~g}$ for control group. While by Day 6 , the mean the body weight for the test groups was $173 \pm 7 \mathrm{~g}$ and in 
Table 3. Observations on Days 6, 7 and 8 of the Streptococcus pneumoniae infected rats.

\begin{tabular}{cll}
\hline Group & Treatment & Observation \\
\hline 1 & No Irvingia spp. paste & Normal activities, raised fur, normal appetite \\
2 & $1 \mathrm{ml}$ of SP and no Irvingia spp. paste & Low activity, improved appetite \\
3 & $1 \mathrm{ml}$ of SP $+50 \mathrm{mg} / \mathrm{kg}$ of Irvingia spp. paste & Active and improved appetite \\
4 & $1 \mathrm{ml}$ of SP $+100 \mathrm{mg} / \mathrm{kg}$ of Irvingia spp. paste & Active and improved appetite \\
5 & $1 \mathrm{ml}$ of SP $+250 \mathrm{mg} / \mathrm{kg}$ of Irvingia spp. paste & Active and improved appetite \\
6 & $1 \mathrm{ml}$ of SP $+500 \mathrm{mg} / \mathrm{kg}$ of Irvingia spp. paste & Active and improved appetite \\
7 & $1 \mathrm{ml}$ of SP + lethal doses $5500,6000,6500,7000$ & Rats injected with 6,500 and $7000 \mathrm{mg} / \mathrm{kg} \mathrm{died}$ \\
\hline
\end{tabular}

Table 4. Body weights and food intake in the test rats versus the control group.

\begin{tabular}{lccc}
\hline Variables & Test groups & Control groups & P \\
\hline Body weight $(\mathbf{g})$ & & & \\
Day 1 & $175 \pm 1.9$ & $176 \pm 1.5$ & 0.23 \\
Day 3 & $169 \pm 13.3$ & $179 \pm 2.6$ & $<0.001$ \\
Day 6 & $173 \pm 7.5$ & $182 \pm 40.5$ & 0.65 \\
Food intake/day (g) & & & \\
Baseline & $27.95 \pm 5.3$ & $28.74 \pm 4.2$ & 0.72 \\
Day 3 & $17.35 \pm 2.2$ & $28.85 \pm 0.5$ & $<0.001$ \\
Day 6 & $26.9 \pm 1.1$ & $29.10 \pm 1.6$ & 0.034 \\
\hline
\end{tabular}

Values are mean \pm Standard deviation; $\mathbf{P}, \mathbf{P}$-value (probability).

the control group recorded $182 \pm 40.5 \mathrm{~g}$. The mean baseline food intake for test Groups (2-7) was 27.95 \pm 5.3 $\mathrm{g}$ and in the control group, it was $28.74 \pm 4.2 \mathrm{~g}$. Day 3 rat groups had mean baseline food intake as $17.35 \pm 2.2 \mathrm{~g}$ for the test groups and $28.85 \pm 0.5 \mathrm{~g}$ for the control group. While by Day 6, the mean food intake for the test groups was $26.9 \pm 1.1 \mathrm{~g}$ and in the control group, it was $29.10 \pm 1.6$ g.

\section{DISCUSSION}

The aim of this research was to ascertain the antimicrobial activity of Irvingia leaf extract against $S$. pneumoniae infected rats, and in a related research on Irvingia antimicrobial activities against two common pathogens, $E$. coli and $S$. aureus, findings revealed that the plant contains chemical constituents which posses antibacterial activity against both bacteria (Nworie et al., 2016).

In this study, the inoculation of $S$. pneumoniae into the healthy adult rats caused the manifestation of various clinical signs of pneumonia such as Inappetence, sluggishness, ruffled hair and hunch back. However, the treatment of pneumonia in the rats with varying doses of Irvingia leaf extract shows a significant effect on the infected rats as many of the observed signs were reversed 3-4 days after Irvingia treatment. In a related research on the antibacterial activity of hot and cold water and ethanolic extract of the leaf and stem bark of $I$. gabonensis. E. coli and S. aureus were susceptible to all the extracts (Kuete et al., 2007).

Findings from this study showed that the mean food intake of rats in the test group reduced from 27.95 to $17.35 \mathrm{~g}$ by Day 3 as a result of lack of appetite. On Day 1 , the mean bodyweight for rats in the test group was $175 \pm 1.9 \mathrm{~g}$ and $176 \pm 1.5 \mathrm{~g}$ in the control group. At Day 3 , it was $169 \pm 13.3 \mathrm{~g}$ for test group and $179 \pm 2.6 \mathrm{~g}$ for control group. On Day 6, the mean body weight for test group was $173 \pm 7 \mathrm{~g}$ and $182 \pm 40.5 \mathrm{~g}$ in the control group. This reveals weight loss in the test group between the Day 1 to Day 6 when the rats started recuperating $(6 \pm 11.4$ to $4 \pm 6.3 \mathrm{~g}$ ). However there is weight increase observed in the control group, which may occur in the test group when kept for about 12 weeks after infection as observed by Fatemeh et al. (2017).

Some other plant extracts reported to show antimicrobial activities in challenged rats is the Cnidoscolus aconitifolius plant extract, which indicated broad spectrum antibacterial activity against $S$. aureus, Shigella spp., Salmonella spp. and S. pneumoniae (Ekeleme et al., 2013). 
In another report, aqueous extract of Vitelleria paradoxa was shown to clear Salmonellosis within twelve days in previously infected rats via single dose oral administration of Salmonella typhimurium (Fodouop et al., 2017). However in this study the rats recovered from the fourth day after oral administration of the Irvingia sp. extract. The lethal doses of Irvingia from this research shows that doses higher than $5500 \mathrm{mg} / \mathrm{kg}$ of the paste extract administered to the infected rats causes death, and a recent research on Spondias mombin effect on rat toxicity which contains similar phytochemicals like Irvingia spp. closely supports this outcome with a lethal dose above $5000 \mathrm{mg} / \mathrm{kg}$ (Muhammad, 2015; Ewere et al., 2016).

\section{Conclusion}

The abundance of the bush mango plant in West and Central Africa should be exploited research-wise because its leaf extract confers antimicrobial activity against Streptococcus pneumoniae and other microbes. The observation is interesting because the plant grows more in the African continent and probably why scientific publications about the plant are still a bit limited. Thus, further research on the bush mango should be aggressively embarked upon, as it may aid in the reduction in the drug resistance, cost of treatment of the disease, economic and research growth/development in the region.

\section{Compliance with ethics and guidelines}

Animals were handled according to the APA Committee on Animal Research and Ethics (CARE).

\section{Conflict of interest}

Authors have no conflict of Interest.

\section{REFERENCES}

Aarde S. M., Angrish D., Barlow D. J., Wright M. J. Jr., Vandewater S. A., Creehan K. M., Houseknecht K. L., Dickerson T. J. \& Taffe M. A. (2013). Mephedrone (4-methylmethcathinone) supports intravenous self-administration in Sprague-Dawley and Wistar rat. Addict. Biol. 18(5):786-799.

Alexander J. E., Lock R., Peters C. A. M., Poolman J. T., Andrew P. R., Mitchell T. J., Hansman D. \& Paton J. C. (1994). Immunization of mice with pneumolysin toxoid confers a significant degree of protection against at least nine serotypes of Streptococcus pnuemoniae. Infect. Immun. 62:5683-5688.

Appelbaum P. C., Bhamjee A., Scragg J. N., Hallett A. F., Bowen A. J. \& Cooper R. C. (1977). Streptococcus pneumonia resistant to penicillin and chloramphenicol. Lancet. 2:995-997.

Arora B. \& Arora B. (2012). Text book of microbiology. Fourth Edition,
CBS Publishers, India.

Ayodele O. S., Timothy A. \& Amusat T. H. (2015). Evaluation of antidiabetic activity of Irvingia gabonensis (Aubry-Lecomte ex O'Rorke) leaf and bark in alloxan induced diabetic rats. Biosciences Research in Today's World. 1(1):84-89.

Ayuk E. T., Duguma B., Franzel S., Kengue J., Mollet M., Tiki-Manga T. \& Zenkeng P. (1999). Uses, management and economic potential of Irvingia gabonensis in the humid lowlands of Cameroon. Forest Ecol. Manage. 113(1):1-8

Benbachir M., Benredjeb S., Boye C. S., Dosso M., Bellabbes H. \& Kamoun A. (2001). Two-year surveillence of antibiotic resistance Streptococcus pneumoniae in four in African cities. Antimicrob. Agents Chemother. 45(2):627-629.

Benjamin P. C., Shepherd R. K., Robins-Browne R. M., Clark G. M. \& O'Leary S. (2006). Pneumococcal meningitis: development of a new animal model. Otol. Neurotol. 27:844-854.

Candiani G., Abbondi M., Borgonovi M. \& Williams R. (1997). Experimental lobar pneumonia due to penicillin-susceptible and penicillin-resistant Streptococcus pneumoniae in immunocompetent and neutropenic rats: efficacy of penicillin and teicoplanin treatment. J. Antimicrob. Chemoth. 39:199-207.

Cardozo D. M., Nascimento-Carvalho C. M., Souza F. R. \& Silva N. M. (2006). Nasopharyngeal colonization and penicillin resistance among pneumococcal strains: a worldwide update (2004). Braz. J. Infec. Dis. 10:293-304.

Darsaud A., Bourdon L., Chevrier C., Keita M., Bouteille B., Queyroy A., Canini F., Cespuglio R., Dumas M. \& Buguet A. (2003). Clinical follow-up in the rat experimental model of African-trypanosomiasis. Exp. Biol. Med. 228:1355.

Doern G. V., Heilmann K. P., Huynh H. K., Rhomberg P. R., Coffman S. L. \& Brueggemann A. B. (2001). Antimicrobial resistance among clinical isolates of Streptococcus pneumonia in the United State during 1999-2000, including a comparison of resistance rates since 1994-1995. Antimicrob. Agents Chemother. 45:1712-1719.

Ekeleme U. G., Nwachukwu N. C., Ogodo A. C., Nnadi C. J., Onuabuchi I. A. \& Osuocha K. U. (2013). Phytochemical Screening and Antibacterial Activity of Cnidoscolus aconitifolius and Associated Changes in Liver Enzymes in Wistar Rats. Aust. J. Basic Appl. Sci. $7(12): 156-162$

Emele F. E. (2000). Etiologic spectrum and pattern of antimicrobial susceptibility in bacterial meningitis in Sokoto, Nigeria. Acta. Pediatr. 89:942-946.

Ewere E. G., Oyebadejo S. A. \& Peter V. C. (2016). Ethanolic leaf extract of Irvingia gabonensis (o'Rorke) Baill protects against nephrotoxocity and hepatotoxicity in cadmium-induced Wistar albino rats. Int. J. Pharmacol Toxicol. 4(2):105-110.

Fatemeh S., Ali T., Mohammad R., Seyed M. L. \& Majid K. (2017). Using rats as a research model to investigate the effect of human adenovirus 36 on weight gain. ARYA Atheroscler. 13(4):167-171.

Fitts D. A. (2011). Ethics and animal numbers: Informal analyses, uncertain sample sizes, inefficient replications. Type 1 errors. J. Am. Assoc. Lab. Anim. Sci. 50(4):445-453.

Fodouop S. P., Tala S. D., Leilah L. P., Kodijo N., Yemele M. D., Kamdje N. A. H., Nji-Kah B., Tchoumboue J. \& Gatsing D. (2017). Effects of Vitellaria paradoxa aqueous leaf extract administration on Salmonella typhimurium-infected rats. BMC Compl. Altern. Med. 17(1):160.

George I. N. \& Zhao Y. (2007). Pharmacological activity of 2,3,8- Tri-omethyl ellagic acid isolation from the stem bark of Irvingia gabonensis. Afri. J. Biotechnol. 6(16):1910-1912.

Harris R., Sabatelli L. M. \& Seeger M. A. (1996). Guidance cues at the Drosophila CNS midline: identification and characterization of two Drosophila Netrin/UNC-6 homologs. Neuron.17(2):217-228.

Hausdorff W. P., Feikin D. R. \& Klugman K. P. (2005). Epidemiological differences among pneumococcal serotypes. Lancet Infect. Dis. 5:83-93.

Hollister-Lock J., El Khattabi I., Marsili A., Weir G. C., Sharma A., Larsen P. R. \& Bonner-Weir S. (2013). Thyroid hormone promotes postnatal rat pancreatic $\beta$-cell development and glucose- responsive insulin secretion through MAFA. Diabetes. 62(5):1569-1580. 
Kuete V., Wabo G. F. \& Ngamerni B. (2007). Antimicrobial Activity of the Methanolic Extract, Fractions and Compounds from the Sterm Bark of Irvingia gabonensis (Ixonanthaceae). J. Ethnophamacol. 114(1): 54-60.

Lowe A. J. A., Gillies C. M., Wilson J. \& Dawson I. K. (2000). Conservation genetic of bush mango from central/West Africa: Implications from random amplified polymorphic DNA analysis. Molecular Techniques. 9: 831-841.

Malann Y. D., Anonymous K. \& Olarewaju C. A. (2014). Antiplasmodial Effect of Ethanoic Leaf Extract of Invirgia gabonensis on Plasmodium berghei in Mice. Global Journal of Current Research. 1(3): 40-45.

Mandell L. A., Wunderink R. G., Anzueto A., Bartlett J. G., Campbell G. D., Dean N. C., Dowell S. F., File T. M., Musher D. M., Niederman M. S., Torres A. \& Whitney C. G. (2007). Infectious Diseases Society of America/American Thoracic Society consensus guidelines on the management of community-acquired pneumonia in adults. Clin. Infect. Dis. 44: 27-72.

Muhammad M. A. (2015). Diuretic and Toxicity Studies of Methanolic Stem Bark Extract of Spondias Mombin Linn (Anacardiaecea) rats. A Dissertation Submission of Post Graduate Studies, Ahmadu Bello University.

Mukherjee P. K. (2002). Quality control of herbal drugs: An approach to evaluation of botanicals. Business Horizons, India.

Murray P. R., Baron E. J., Jorgensen J. H., Pfaller M. A. \& Yolken R. H. (2003). Manual of Clinical Microbiology, Eight Edition. ASM Press, Washington, DC.

Ngondi J. L., Oben J. E. \& Minka S. R. (2005). The effect of Irvingia gabonensis seeds on body weight and blood lipids of obese subject in Cameroon. Lipids Health Dis. 4: 12.

Nworie O., Orji J. O., Ekuma U. O., Agah M. V., Okoli C. S. \& Nweke M. C. (2016). Antibacterial Activity of the Leaf and Stem Bark of Irvingia gabonensis (Bush Mango) Against Escherichia coli and Staphylococcus aureus. Glob J. Pharmacol. 10(1): 13-18.
Okolo C. O., Johnson P. B., Abdurahman E. M., Abdu-Aguye I. \& Hussaini I. M. (1995). Analgesic effect of Irvingia gabonensis stem bark extract. J. Ethnopharmacol. 2(45):125-129.

Oluwafemi A. O., Basiru O. A., Babatunji E. O., Adebola B. O. \& Olaide I. O. (2014). Prophylatic effects of ethanolic extracts of irvingia gabonensis stem bark against cadmium-induced toxicity in albino rat. Interdiscip Toxicol. 7(4):208-214.

Richard A. S., Anne M. S., Gary R. F., Cluadelte M. T., David E. B., Les K. \& George R. S. (1997). Development of a model of low inoculum Streptococcus pneumoniae intrapulmonary infection in infant rats. Am. J. Microbiol. 65:4701-4704.

Richard M., Anne M. S., Robert N. H., Cluadelte M. T., Gary R. F. \& Richard A. S. (2004). Development of a model of focal Pnuemococcal pneumonia in young rats. J. Immun. Based Ther. Vaccines. 2(1):2.

Samadder A. \& Khuda-Bukhsh A. R. (2014). Nanotechnological approaches in diabetes treatment: A new horizon. World J. Transl. Med. 3(2):84-95.

Shakya V. K., Saxena R. C. \& Shakya A. (2010). Effect of ethanolic extract of Allium sativum bulbs on Streptozotocin induced diabetic rats. J. Chem. Pharm. Res. 2(6):171-175.

Smith G. M. \& Abbott K. H. (1994). Development of experimental respiratory infections inneutropenic rats with either penicillin-resistant Streptococcus pneumoniae or -lactamase-producing Haemophilus influenzae. Antimicrob. Agents Chemother. 38:608-610. 